\title{
A PHENOMENOLOGICAL EXPLORATION OF AdAPTATION IN A POLYCONTEXTUAL WORK ENVIRONMENT
}

\section{P.C. van Fenema and S. Qureshi}

\begin{tabular}{|l|l|}
\hline \multicolumn{2}{|l|}{ ERIM REPORT SERIES RESEARCH IN MANAGEMENT } \\
\hline ERIM Report Series reference number & ERS-2004-061-LIS \\
\hline Publication & June 2004 \\
\hline Number of pages & 17 \\
\hline Email address corresponding author & pfenema@fbk.eur.nl \\
\hline Address & Erasmus Research Institute of Management (ERIM) \\
& Rotterdam School of Management / Rotterdam School of \\
& Economics \\
& Erasmus Universiteit Rotterdam \\
& P.O. Box 1738 \\
& 3000 DR Rotterdam, The Netherlands \\
& Phone: +31 10 408 1182 \\
& Fax: +31 10 408 9640 \\
& Email: info@erim.eur.nl \\
& Internet: www.erim.eur.nl \\
\hline
\end{tabular}

Bibliographic data and classifications of all the ERIM reports are also available on the ERIM website: www.erim.eur.nl 


\title{
ERASMUS RESEARCH INSTITUTE OF MANAGEMENT
}

\author{
REPORT SERIES \\ RESEARCH IN MANAGEMENT
}

\begin{tabular}{|c|c|c|}
\hline \multicolumn{3}{|c|}{ BIBLIOGRAPHIC DATA AND CLASSIFICATIONS } \\
\hline Abstract & \multicolumn{2}{|c|}{$\begin{array}{l}\text { The rise of new ways of working through the use of information and communication technology } \\
\text { brings about new phenomena that are powerful in the effects that they have on people. The } \\
\text { potency of phenomenology lies in its philosophical simplicity and it provides the researcher with } \\
\text { the ability to study the essence of an observable but scarcely understood phenomena: How do } \\
\text { people perform effectively and efficiently in a geographically and temporally dispersed work } \\
\text { environment? Collective action across multiple time zones continues to challenge both } \\
\text { academics and practioners. This study provides a unique view of how globally dispersed } \\
\text { participants achieve collective action. It throws light into how the creation of shared } \\
\text { understanding is tempered by differences in time zones and how participants adapt through their } \\
\text { choice of media, work practices and communication. Following an analysis of a case studied } \\
\text { using phenomenology, this paper concludes with a model of adaptation in polycontextual work } \\
\text { environments. }\end{array}$} \\
\hline \multirow{3}{*}{$\begin{array}{l}\text { Library of Congress } \\
\text { Classification } \\
\text { (LCC) }\end{array}$} & $5001-6182$ & Business \\
\hline & $5201-5982$ & Business Science \\
\hline & $\begin{array}{l}\text { HD 66+ } \\
\text { HD 30.2+ }\end{array}$ & $\begin{array}{l}\text { Work groups: management } \\
\text { Information Technology management }\end{array}$ \\
\hline \multirow{4}{*}{$\begin{array}{l}\text { Journal of Economic } \\
\text { Literature } \\
\text { (JEL) }\end{array}$} & M & Business Administration and Business Economics \\
\hline & M 11 & Production Management \\
\hline & R 4 & Transportation Systems \\
\hline & $\mathrm{J} 29$ & Work behavior: other \\
\hline \multirow{5}{*}{$\begin{array}{l}\text { European Business Schools } \\
\text { Library Group } \\
\text { (EBSLG) }\end{array}$} & $85 \mathrm{~A}$ & Business General \\
\hline & $260 \mathrm{~K}$ & Logistics \\
\hline & $240 \mathrm{~B}$ & Information Systems Management \\
\hline & $60 \mathrm{~A}$ & Intercultural communication \\
\hline & $130 \mathrm{G}$ & Influence of technology on work organization \\
\hline \multicolumn{3}{|c|}{ Gemeenschappelijke Onderwerpsontsluiting (GOO) } \\
\hline \multirow[t]{4}{*}{ Classification GOO } & 85.00 & Bedrijfskunde, Organisatiekunde: algemeen \\
\hline & 85.34 & Logistiek management \\
\hline & 85.20 & Bestuurlijke informatie, informatieverzorging \\
\hline & 85.53 & Arbeidsorganisatie \\
\hline \multirow[t]{3}{*}{ Keywords GOO } & \multicolumn{2}{|c|}{ Bedrijfskunde / Bedrijfseconomie } \\
\hline & \multicolumn{2}{|c|}{ Bedrijfsprocessen, logistiek, management informatiesystemen } \\
\hline & \multicolumn{2}{|c|}{ Virtuele organisatie, werkomgeving, } \\
\hline Free keywords & \multicolumn{2}{|c|}{$\begin{array}{l}\text { polycontextuality, adaptation, phenomenology, life-worlds, asyncronous collective action, shared } \\
\text { understanding }\end{array}$} \\
\hline
\end{tabular}




\title{
A Phenomenological Exploration of Adaptation in a Polycontextual Work Environment
}

Paul C. van Fenema

Erasmus University

Rotterdam School of Management

P.O. Box 1738

3000 DR Rotterdam, The Netherlands

E-mail: Pfenema@fbk.eur.nl

Sajda Qureshi

University of Nebraska at Omaha

College of Information Science and Technology

The Peter Kiewit Institute

Omaha, NE 68182-0392

And

Rotterdam School of Management

Erasmus University Rotterdam

Email: squreshi@mail.unomaha.edu

\begin{abstract}
The rise of new ways of working through the use of information and communication technology brings about new phenomena that are powerful in the effects that they have on people. The potency of phenomenology lies in its philosophical simplicity and it provides the researcher with the ability to study the essence of an observable but scarcely understood phenomena: How do people perform effectively and efficiently in a geographically and temporally dispersed work environment? Collective action across multiple time zones continues to challenge both academics and practioners. This study provides a unique view of how globally dispersed participants achieve collective action. It throws light into how the creation of shared understanding is tempered by differences in time zones and how participants adapt through their choice of media, work practices and communication. Following an analysis of a case studied using phenomenology, this paper concludes with a model of adaptation in polycontextual work environments.
\end{abstract}

\section{INTRODUCTION}

Collective action underpins today's work environments where performance requirements exceed individuals' cognitive, physical and social capacities. With the widespread availability of advanced technology, collective action has become more complex as it is more and more geographically dispersed. Collaboration across globally dispersed sites has given rise to paradoxes that had not been previously encountered. Qureshi and Zigurs (2001) suggest that collaborative technologies used in virtual environments enable better face to face meetings, cultural differences increase the resolve to connect in virtual collaborations, and simple and adaptable technologies enable more complex virtual collaboration. Time zone differences and their impact on collaboration have been studied in areas such as New Product Development (Meadows, 1996a), and R\&D (Andres, 1992, Chiesa, 1995). Uncertainty in a collaborative relationships could lead to a chain of asynchronous exchanges and thus delays. In order to avoid this 'Ping-Pong' scenario, (Quain, 1997) where people invest in uncertainty-reduction by crafting 
comprehensive messages. Meadows (1996a) also found that people work in day and night shifts to absorb inconveniences caused by time zone differences.

Global dispersion complicates the coordination of collective action in several ways. First, it implies physical distance and a shift towards remote communications(Evaristo \& van Fenema, 1999). Second, people joining from different sites bring their unique sociocultural background, thus adding to the diversity of globalized collective action (Krauss \& Fussell, 1990). And third, time zone differences disrupt interaction flows across sites. Over recent years, a mixed picture has been sketched on this third factor. On the one hand, people have claimed that time differences stretch working days. Their work could 'follow the sun'. This suggests that sites can pass on intermediate deliverables or questions at the end of a working day to a site west from theirs where a new day has just begun (Carmel \& Zettl-Schaffer, 1997). A sequential relay race would spin the globe and never stop until the work is finished. On the other hand, time zones delay work accomplishment (Knoll \& Jarvenpaa, 1998; Meadows, 1996b). People miss real-time phone conversations and chats that would solve problems in a short time frame. Instead, they have to shift towards a more asynchronous communication pattern that lengthens problem solving cycles.

The questions that remain to be answered are: how does distributed collaboration takes place? and what are the characteristics of this increasingly ubiquitous phenomenon? As these questions continue to elude researchers and practioners, phenomenology appears to be particularly well suited to investigating how people work together in a geographically and temporally dispersed electronic spaces. This is because, phenomenology enables the context, language, symbolism and imagery to be discerned from the life worlds investigated. Life worlds provide views of individual social actors who are creative and proactive. Their dialogue throws valuable light into what is collective action through distributed collaboration according to the social actors? How do social actors carry out collective action through distributed collaboration? What are the processes through which they go through?

In attempting to delineate the contours of this intriguing phenomenon, this paper explores the life worlds of people working distributedly in a software development project. The first is a global software development project where an international car manufacturer outsourced software development to an offshore vendor in India. The second project concerns the implementation of Oracle ERP in the Far East region at a firm that manufactures storage products. This study provides a unique view of how intersubjectivity develops in social actors located in widely spread geographical locations whose communicative action is tempered by differences in time zones. The life worlds described in this paper develop through dialogue in electronic spaces supported by communication and software development technologies. The life of these worlds is created through dialogue, images and actions. In this way, this paper investigates how collective action across multiple time zones can be created through adaptation in polycontextual work environments. Following an analysis of a case studied using phenomenology, this paper concludes with a model of adaptation in polycontextual work environments.

\section{APPROACH OF THIS RESEARCH}

This research follows a phenomenological approach. The phenomenological view of organisation is seen as a "life-world" or "social-world" that is created, maintained and generated through intersubjectivity according to writers such as Habermas (1984), 
Husserl (1982), and Schutz (1967). A central focus of the concept of the "life world" is how subjective meanings become objective facticities (Berger and Luckman 1991). Intersubjectivity is the state of sharing the understanding of others and the mechanism of bringing the conception of being "normal" in the community (Habermas 1984). According to Weick, intersubjectivity has two defining characteristics: 1) it emerges from the interchange and synthesis of meanings among two or more communicating people, and 2) the subject gets transformed during interaction such that a joint or merged subjectivity develops (Weick 2001).

Through communicating with language community members believe that they share perceptions and understanding with each other, and such a shared understanding is real in their minds (Chikudate 1997). When the social construction of reality governed by intersubjectivity is controlled by language, according to Searle (1995), language is seen to be a tool of accessing each other's life-world. Merleau-Ponty (1963) suggests that the most exact characteristics of a word is embedded in the related perceptions. Significance exists not within a word but in relation to the context given by other words.

However, while language is important in enabling the researcher to build an understanding of intersubjectivity, it can also detract from the essence of the phenomenon being studied. Language can become a limiting factor when a subject is at a loss for words, has difficulty using a language, or a concept or set of concepts emerge that cannot be adequately described using the current vocabulary. Further elaboration of questions and counter-questions involves a philosophy of essence, metaphors, of the impact and influence of images, symbolism and codifying systems.

The case concerns the implementation of Oracle ERP in the Far East region at a firm that manufactures storage products. This study provides a unique view of how intersubjectivity develops in social actors located in widely spread geographical locations whose communicative action is tempered by differences in time zones. The case investigated in this paper throws light into how collective action across multiple time zones can be created through adaptation in polycontextual work environments. Our analysis intends to embed the data in a conceptual understanding that combines view points like coordination, communication, and organization theory. These perspectives are added whenever we felt the data asked for it. They frame interviews such that a coherent insight emerges. The paper thus moves from individual data points towards intersubjective understanding (Lee, 1991). Staying as closely as possible to the data improves the quality of the 'theory' that emerges. It reduces the risk of coming up with concepts that seem disconnected from the world they try to explain. The paper concludes with a reflective integration of our own findings with current literature.

\section{THE RESEARCH SETTING: MULTI-SITE IMPLEMENTATION OF ERP SOFTWARE}

DiskCo ${ }^{1}$ is a multinational manufacturer of data storage products - hard disks, tape drives, and storage media and software. Our study focused on the implementation of ERP (Enterprise Resource Planning) software in the Far East. The project in that region covered Singapore, Malaysia, China, and Japan. It was coordinated by DiskCo's regional headquarters (HQ) in Singapore and Malaysia, and followed earlier conversions in North America. The group with responsibility for the Far East worked closely with US counterparts to learn from their experiences. Time zone differences played a role in these collaborative relationships. Table 1 shows working days (8 AM - 7 PM) for DiskCo

\footnotetext{
${ }^{1}$ Not real name for reasons of confidentiality.
} 
sites in Singapore and US Pacific and Central time zones. Within these constraints, dotted horizontal lines indicate windows for real-time exchanges. We analyze here interviews with project members in Singapore and Malaysia. Interviews were conducted face-to-face in Singapore, and through teleconferences with people in Malaysia whilst staying in Singapore.

This case represents a polycontextual work environment (Engeström 1995). This means that the participants in this case were not only geographically dispersed but also grappled with time zone differences. Participants were required to work with colleagues from different parts of the world who possessed different working habits to their own and different levels of knowledge and skill that were required to complete the project in which they were working on together. The temporal dispersion added an extra element to be coordinated in this interdependent work environment. Staff in Singapore frequently consulted American colleagues for assistance on the implementation of the ERP system. These counterparts worked either at corporate HQ in the US Pacific zone, or another plant in US Central time zone. When faced with burning issues, Singaporean staff came early to work to catch staff at the US Pacific site during their late afternoon. They adapted their working habits to deal with urgent dependence on remote counterparts. This was hardly feasible with US Central sites. As Table 1 indicates, a window requires accommodation on both sides - Singaporeans coming in early, and Americans staying late in the office. A Singaporean team member explains:

"Sometimes if you really need to talk to them, it depends on which site. Like [US Pacific] normally if we come in early, it will be their evening and we can still talk to each other. But [US Central], the people who are working in that time zone, we can hardly meet each other." - SCC, DiskCo-J-1

Table 1 - Time zones DiskCo sites

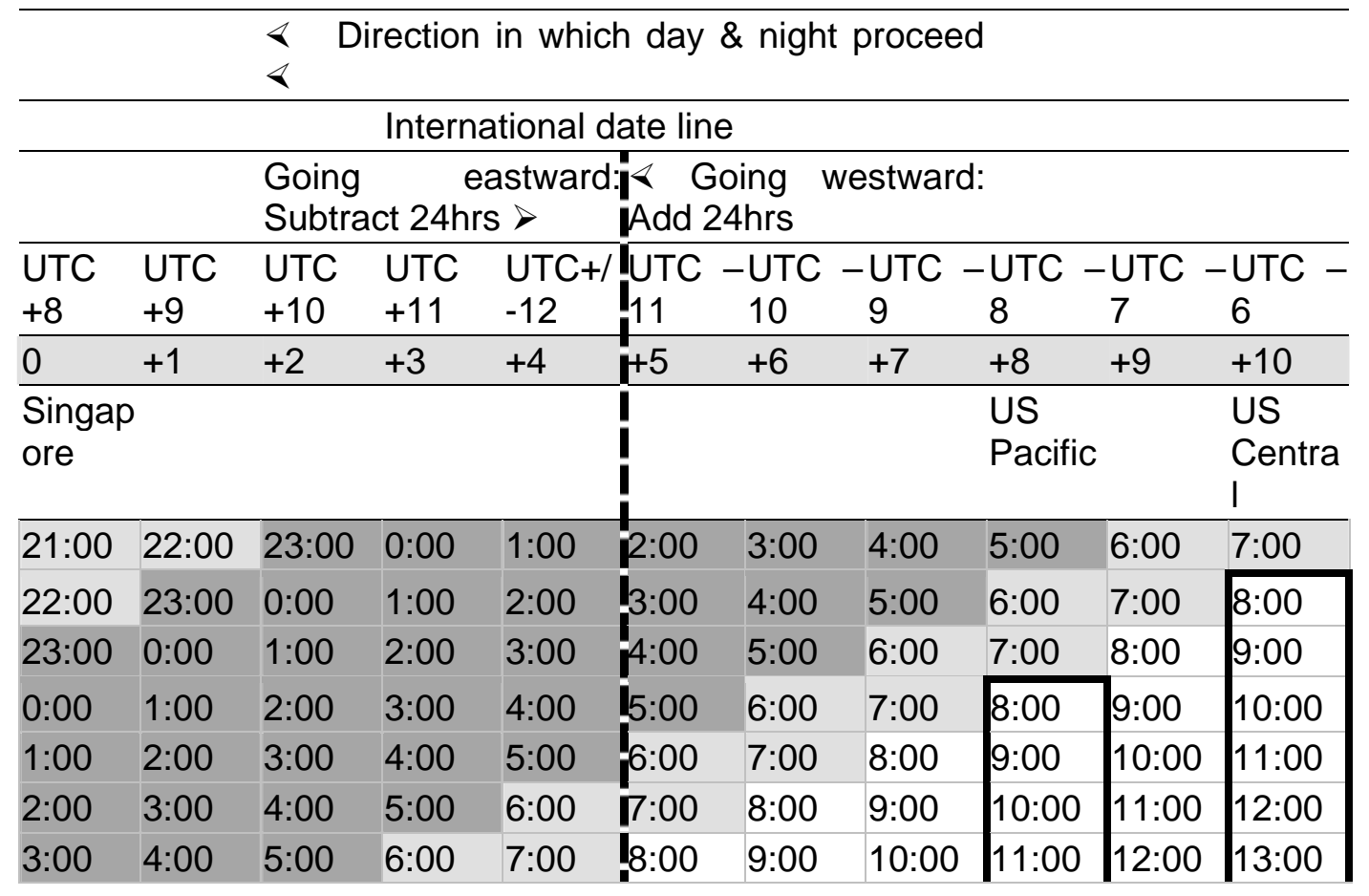




\begin{tabular}{|c|c|c|c|c|c|c|c|c|c|c|}
\hline 4:00 & 5:00 & 6:00 & 7:00 & 8:00 & 9:00 & $10: 00$ & $11: 00$ & $12: 00$ & $13: 00$ & 14:00 \\
\hline 5:00 & $: 00$ & 7:00 & 8:00 & 9:00 & LO:00 & $11: 00$ & $12: 00$ & $13: 00$ & $14: 00$ & $15: 00$ \\
\hline $6: 00$ & 7:00 & 8:00 & $: 00$ & 10:00 & L:00 & $12: 00$ & $13: 00$ & $14: 00$ & $15: 00$ & $16: 00$ \\
\hline 7:00 & 00 & 9:00 & & $11: 00$ & $2: 00$ & $13: 00$ & & $15: 00$ & $16: 00$ & $17: 00$ \\
\hline 00 & & & & & & & & 16:00 & 17:00 & 18:00 \\
\hline & & & $12: 00$ & $13: 00$ & $14: 00$ & $15: 00$ & & & 18:00 & $19: 00$ \\
\hline & & & & & & & & & 19:00 & 20:00 \\
\hline ח. 1. & $12: 00$ & 13:00 & & $15: 00$ & $6: 00$ & $17: 00$ & & 19:00 & 20:00 & $21: 00$ \\
\hline & & & & & & $18: 00$ & & 20:00 & 21:00 & 22:00 \\
\hline 3:00 & $14: 00$ & $15: 00$ & $16: 00$ & $17: 00$ & 18:00 & 19:00 & 20:00 & 21:00 & $22: 00$ & 23:00 \\
\hline $14: 00$ & $15: 00$ & $16: 00$ & $17: 00$ & $18: 00$ & 19:00 & 20:00 & 21:00 & 22:00 & 23:00 & 0:00 \\
\hline $15: 00$ & $16: 00$ & $17: 00$ & $18: 00$ & 19:00 & :00 & $21: 00$ & $22: 00$ & 23:00 & $0: 00$ & $1: 00$ \\
\hline $6: 00$ & $17: 00$ & 18:00 & 19:00 & 20:00 & 1:00 & $22: 00$ & $23: 00$ & $0: 00$ & $1: 00$ & $2: 00$ \\
\hline 7:00 & 18:00 & 19:00 & 20:00 & 21:00 & |22:00 & 23:00 & 0:00 & $1: 00$ & 2:00 & 3:00 \\
\hline 18:00 & 19:00 & 20:00 & 21: & $22: 00$ & $23: 00$ & 0:00 & 1: & $2: 00$ & 3:00 & 4:00 \\
\hline 19:00 & 20:00 & 21:00 & $22: 00$ & 23:00 & $0: 00$ & $1: 00$ & & $3: 00$ & $4: 00$ & 5:00 \\
\hline :00 & $21: 00$ & $22: 00$ & 23:00 & $0: 00$ & :00 & $2: 00$ & $3: 00$ & $4: 00$ & 5:00 & $6: 00$ \\
\hline 21:00 & 22:00 & 23:00 & 0:00 & $1: 00$ & $2: 00$ & $3: 00$ & $4: 00$ & $5: 00$ & $6: 00$ & 7:00 \\
\hline 2:00 & 23:00 & 0:00 & $1: 00$ & $2: 00$ & 3:00 & 4:00 & 5:00 & $6: 00$ & $7: 00$ & 8:00 \\
\hline 3:00 & 0:00 & 1:00 & 2:00 & 3:00 & $4: 00$ & 5:00 & $6: 00$ & 7:00 & 8:00 & 9:00 \\
\hline $\begin{array}{l}\text { UTC } \\
+8\end{array}$ & $\begin{array}{l}\text { UTC } \\
+9\end{array}$ & $\begin{array}{l}\text { UTC } \\
+10\end{array}$ & $\begin{array}{l}\text { UTC } \\
+11\end{array}$ & $\begin{array}{l}\text { UTC+I } \\
-12\end{array}$ & $\begin{array}{l}\text { fUTC } \\
11\end{array}$ & $\begin{array}{c}- \text { UTC } \\
10\end{array}$ & $\begin{array}{l}\text { UTC } \\
9\end{array}$ & $\begin{array}{l}-U T C \\
8\end{array}$ & $\begin{array}{c}-U T C \\
7\end{array}$ & $\begin{array}{c}-U T C \\
6\end{array}$ \\
\hline
\end{tabular}

Daylight Saving Time (DST) not applied

\section{ADAPTATION IN A POLYCONTEXTUAL WORK ENVIRONMENT}

The results of the DiskCo case are reported in the following sections. The Phenomenological accounts in which intersubjectivity is created are depicted as transcripts of quotes from participants interacting in this polycontextual work environment. Most of these quotes were obtained through open interviews and discussions with participants. The creation of joint subjectivity is interpreted through observations of their interactions in their work environments and using insights from authors who have also observed and investigated similar concepts. By interpreting the data using relevant literature, our analysis of the observed phenomenon enables a strong conceptual understanding of adaptation on polycontextual work environments to be arrived at.

\section{Media Choice}

Time zone differences affect media choice. The participants use asynchronous media to deal with partially disconnected time frames. They leave a mediated representation of their communicative action for retrieval at the receiver's convenience. Email and voice mail constitute bubbles of independent communications that connect people from different contexts, without immediate personal feedback. Consequently, this practice delays interactive tasks. It interrupts reciprocal communication flows needed for multiactor problem solving. 
"The main tools we are using is email to communicate with the US. We hardly ring them because of the time difference. If let's say other sites like China, Malaysia normally we will try to call them instead of writing an email. It's faster that way in the sense that you are able to reach them." - SCC, DiskCo-J-1

Another team member from the same site echoes the fact that time zone differences induce use of asynchronous media. Real-time contact is unlikely given the considerable time laps between Singapore and US. This delays collaborative work that requires interactive fine-tuning. In her case, she needed help from American colleagues on an Oracle implementation issue. To this end, she presented her problem, but often received a counter request for clarifying certain issues.

Task uncertainty led to reciprocal information sharing needs, i.e., adjustive coordination (Williamson, 1991). This constitutes a more intense and unstructured form of connecting than relay type of collaborative relationships (e.g., passing on codes that must be checked). The latter could be sequentially modeled after time zone differences (Carmel \& Zettl-Schaffer, 1997; Van de Ven, Delbecq, \& Koenig Jr, 1976). With the former type, asynchronicity is merely a nuisance:

"Because US is few hours behind us - when I have a problem now, I write mail to them. Well, we can't call them: They will be sleeping, nobody will be answering the phone. So I'll have to write mail. And I need to wait for a few hours until they start working and until they start reading their mail. And when they read their mail, probably I'm sleeping, you know. So that is why because of the time difference, we cannot really resolve problems in a shorter time. (...) When you work with US people, then because of the time difference you need days [emphasis] to solve the problem. It's some unnecessary delay." - OBT, DiskCoC-1

\section{Shift in Media Choice}

The shift to asynchronous media increased the importance of crafting comprehensive messages. This reduces information dependence. Remaining uncertainty stretches the chain of interactions, exacerbated by time zone differences. In practice, feedback loops remain inevitable for clarifications. Problem owner (in Singapore and Malaysia) and experts (US) shared little collaborative history. While an attempt is made to implement globally standardized ERP software, they have always operated in different contexts (Soh, Kien, \& Tay-Yap, 2000). This makes their perceptions, expertise, and expectations unique, i.e., non-shared (Weick, 1993). In DiskCo's case, sites in the Far East and North America were diversely specialized: The former in large scale manufacturing, the latter in R\&D. This added to the complexity of information exchanges. Americans could not easily relate to the Singaporeans' problem situation, simply because they were not familiar with their operational context (Dougherty, 1992):

"Because Singapore site A (DiskCo regional HQ Far East) is a main manufacturing firm, we have huge volumes. To them (US - author) it is mainly for $R \& D$. So usually when we have some issues, they will not see the problem. Usually IT (from US - author) will say: "How come Singapore site A you have that issue?" The volume is different, we have a higher volume. There is a difference here, but they will not really see our problem. Because sometimes there are some system problems, their sites do not have the problem, but our site has the problem." - ST, DiskCo-H-1 


\section{Knowledge Gaps}

Lack of mutual awareness was reciprocal. Not only was it challenging for the Americans to frame Far East issues. Conversely, Singaporeans faced the challenge of explaining their problem to people specialized in Oracle but unfamiliar with their operations. A situation of multiple knowledge gaps emerged, as summarized in Table 2.

Table 2 - Knowledge gaps

\begin{tabular}{l|l|l|}
\multicolumn{1}{l}{} & \multicolumn{1}{l}{ Oracle expertise } & \multicolumn{1}{c}{$\begin{array}{l}\text { Knowledge of Far East } \\
\text { operations }\end{array}$} \\
\cline { 2 - 3 } $\begin{array}{l}\text { DiskCo Singapore/ } \\
\text { Malaysia }\end{array}$ & Basic level & Extensive \\
\cline { 2 - 3 } DiskCo US & Experienced & Limited \\
\cline { 2 - 3 }
\end{tabular}

Knowledge gaps on both sides would not matter without task interdependence. But implementing Oracle in the Far East demanded blending of application expertise with local savviness (Grant, 1996b). Singaporeans had to tap into DiskCo-specific Oracle experience available at US HQ. (They could not source from Oracle Singapore since people lacked know-how on the DiskCo business.) Meaningful advice would have to rely on context-specific awareness. All together, task dependence combined with knowledge gaps triggered communication flows. People could not assume their counterparts to know what they knew. They had to become more heedful, and return to basic dimensions of collaborative exchanges (Chwe, 2001; Weick \& Roberts, 1993).

\section{Feedback Communications}

With time zone differences, this translated into a pattern of asynchronous messages. The challenge became to avoid too many feedback loops. People in Singapore and Malaysia attempted to frame their questions such that their American counterparts could grasp a problem, and submit a reply that fit the Far East context. A Malaysian project member formulated this as follows:

"When you read their mails you find that they (US colleagues - author) are very open and they are also very helpful when you ask them information. They share them freely with you. But you have to make sure that you ask them the right questions. Sometimes I find that if you do not ask the right questions, then they will come back to you with more questions. So you have to make sure you ask them all the questions together so that you don't waste time to read for them to come back with other questions again.

I guess maybe one of the differences is because in terms of our DiskCo business in the US, they are more on the Research \& Development side, whereas in the Far East here we are more in the manufacturing kind of business. So they may not fully understand our way of business, and we may not understand their environment there. So sometimes when we ask some questions, they may not be able to visualize what actually is the scenario that we are working on. So that 
could explain why sometimes we need to make sure we ask the right questions." - JNL, DiskCo-F-1

For American DiskCo staff, Singaporeans had to transfer knowledge on their local context, commonly considered 'sticky' (von Hippel, 1994). Those working in the Far East environment naturally absorb the mode of operating there. But people from outside have no part in this common, tacit knowledge base. Related to this are the distance and time zone factor. Locally, face-to-face discussions clarify expectations from one group to an 'outsider'.

\section{Development of Shared Understanding}

Staff in Singapore and the US had to rely on electronic media to represent their life worlds. This reduced the richness of a challenging collaborative process (Daft \& Lewin, 1984).

"I can have a very high priority, but at the time when they (US colleagues) are sleeping they won't answer me. It's not that they have to wait for my mail to come in 24 hours and immediately reply me. Same thing with me: When I'm not working, I'm not reading my mail." - JLL, DiskCo-G-1 (DiskCo team member Singapore)

In addition, time zone differences enforced an exchange mode that was asynchronous and documented instead of interpersonal. People seemed able to achieve similar results compared to co-located situations. It only took them longer as a Singaporean team member points out:

"The final result (of working with US colleagues - author) - yes it's the same (as compared with local, on-site collaboration - author), but sometimes you have to go through 2 or 4 loops of email exchanges. I mean with email you have to clarify so many times. So that is a bit time consuming. But with the local user you can talk face-to-face, and understand their operation immediately.

Especially with US, that is more difficult because the time is different. So it takes more time. We can send them one mail and it's the end of our day, they come back, it's still not clear, you have to wait for another day, for another reply. So that part is the difference if you compare with local." - JLL, DiskCo-G-1

Communication patterns changed to reduce delays. People tried to anticipate their counterparts' position. They conveyed their request as comprehensively as possible in documented (textual) format. One team member from Singapore described his almost form-type of exchange, somewhat like a tax or insurance form. Structured exchange works both sides. It facilitates the counterpart's role, and ensures that replies meet the sender's expectations:

"Time zone may be different, so there is always a delay in getting answers. With China we do not have much of a problem, but between US and Singapore we do. Sometimes when they (colleagues from China) ask me a question I may not be able to answer them, I have to forward it to the US. By the time they give me a reply, it's already night there, it's day here. He may not understand my question properly. So he may not give the right answer. He may just come up "Please elaborate more," or "Give me please one day since I have to go back." 
(...) "So I have to be very very careful in my approaches. I try to put up my question in point forms. When you look at points, people tend to answer to each. But if you put it in a paragraph, it's very difficult for people to answer the question. Because he may miss out the question in between the lines. So I think the best communication is: Put in point forms. When people reply, they will answer the point forms. They will put answers to each point form." - JPL, DiskCo-I-1

Real-time contact between Far East and US sites still played a role despite the availability of asynchronous exchanges. Sometimes, people wanted to setup a conference call between US and Singapore. Only a small window was available to accomplish this, see Table 1.

\section{Adaptation to Globally Distributed Work}

Participants created artificial ${ }^{2}$ windows by adapting working hours, usually on the side of Singapore. An IT director from Singapore mentions her experience with DiskCo's site in US Central time zone:

"As compared to US of course we have more problems there, because it's in a different time zone. So the communication is not as easy (as in the Far East region - author), it's not really a phone call away in that sense. Because when I call them they are sleeping. And then when they want to have a conference meeting, it's always we have to either come very early to the office so that they are in the evening time, or very often we have to actually have conference call from home. So that the call is in their day time. So that can be a bit of inconvenience(...). I would say the first year (of the Oracle ERP project - author), we were having conference call every weeks. And this could take hours." - HHT, DiskCo-B-1

Some people adapted on a more structural basis while they collaborated across time zones. One interviewee indicates that she stretched her days for the ERP project. Because of the $\mathrm{Y} 2 \mathrm{~K}$ problem, the Singaporean team worked under strong time pressure to implement Oracle ERP. Before July 1999 the system had to go live in the Far East. The team depended on US experience with earlier conversion projects. Consequently, they wanted quick problem solving cycles despite the time zone differences. This interviewee accomplished that by returning to the office at night to catch US counterparts during their day:

"(...) I have to communicate a lot with the US site. So now my working time has slightly changed. After work I start work again at 10 PM to 2 AM. I have to do that because I get a lot faster response by just writing mail at my 12 o'clock (Singapore night - author) and they receive it at 8 o'clock (US morning - author). They reply me and let's say I need clarification, I can immediately write back. I can even call them at the time when they are working. I can get faster reply." JLL, DiskCo-G-1

Another interviewee from Singapore echoed the importance of real-time contact with US colleagues. He evaluated two scenarios for artificial windows. First, staying late at night in Singapore to catch Americans in the morning (similar to the preceding quote). This strategy run the risk of Americans coming in late or not being able to give first priority to

\footnotetext{
${ }^{2}$ Artificial in the sense of working outside working hours considered normal in a particular time zone.
} 
Singaporean requests. A second option was to submit an issue to the US by the end of a working day in Singapore. Then Americans pick up the problem in the morning and elaborate it during their working day. Then this interviewee would come in very early in the morning when it is afternoon in the US. Americans would have had a whole day to look at an issue:

"We have to go back late, or come in early. Because about 10 or 11 o'clock evening here is about 7 o'clock AM in the US maybe around there. So either you may have the habit of coming early in the next morning, or you stay late through the night. But staying late through the night is not a good suggestion because when they come in early they are fresh, they may do not want start on your issue. You need to understand their culture - they first want a cup of coffee, they do not want to do their work that early you know.

So it's better you come early in the morning (Singapore time - author), maybe about 6 or 7 o'clock to solve the problem while it's 4 or 5 PM there. So you have given them the time to look at the problem. And this is important for them to understand the problem. Then they get back to you. This is much more fruitful rather than to interrupt them early in the morning. Their early morning is our midnight, you say "Hey I stayed back in the office, can you solve this" - it's quite difficult. So to be fair: since it's your problem, it's best that you come early next morning to try and solve it early in the morning. So for us solving the problem early in the morning is the best thing we can do." - JPL, DiskCo-I-1

Adaptation occurred mostly on the Singaporean side since they needed to tap into US experience. They changed their hours not only during working days, but continued during weekends. On Saturdays some people would return to the office to catch Americans during their Friday afternoon. One of the top rows in Table 1 indicates that going from east to west across the international date line requires subtracting 24 hours, and adding 24 hours when going in the opposite direction. This means that the windows cross one day. In Singapore it could be Saturday already, while Americans are still working in the previous day. One Singaporean used this date differential for expediting problem solving. He returned Saturday morning to solve problems that would otherwise have to wait until Tuesday (Singapore time). After the weekend the date difference worked to his disadvantage:

"We have to adjust ourselves sometimes. Sometimes we even come back on a Saturday morning. Because our Saturday morning is their Friday afternoon actually. And if we don't solve it on Saturday that means we can't solve it on Monday because Monday is their Sunday. Then we only get an answer on Tuesday. But sometimes people are kind enough: when they hear there is a problem to be solved, they give us their home number. And during our live implementation, they are on stand-by, we have their home number to call. They are also stand-by on email and so. So they understand there is a job to be done. So we sign them in during the dates and so on. So everybody is on stand-by." JPL, DiskCo-I-1

Working for the same company promoted priority congruence on both sides of the Pacific ocean (Ouchi, 1977; Williamson, 1985). So adaptation occurred on the US side as well. The ERP implementations in the Far East were critical and time pressed. Specialists in the US remained on stand-by during vital phases. This supportive behavior 
included accessibility from home. In critical work phases, synchronous exchanges can be of vital importance. An implication is that time zones demand adaptations of scheduling work/ private hours. A Malaysian project member summarizes her experience as follows:

"Yeah, it's all by email. Once a while by phone. Because of the time difference. So we usually use email instead of phone. Yes the time zone differences delay. Especially for urgent issues we have a lot of difficulty. (...) Sometimes we cannot get hold of them then we have to loose one day. (...) We have not a procedure for dealing with delays. But instead, if there is a really urgent issue, then we will contact them (US specialists - author) at home." - MC, DiskCo-E-1

Sometimes, issues demand urgent attention, but do not justify contacting people at home. Interviewees deployed asynchronous messaging to arrange for real-time telemeetings. For instance, a collaborative topic surfaced in the Far East when people were not in at US sites. On these occasions, people would send an email to setup a meeting at the first possible time frame - Singapore morning, corresponding to US afternoon/ evening (Table 1):

"For US for urgent cases, normally what I will do is I will send them a mail to make an appointment with them to have a teleconference so that the next day when we come in early in the morning we are able to catch them in the US." JNL, DiskCo-F-1

Overall, time zones delayed problem solving. They interrupted speedy attention of a counterpart in another country. Circumventing this effect suggests reduction of dependence on remote experts. In DiskCo's case, US sites adopted the ERP system earlier than Far East sites. They had accumulated therefore a substantial knowledge base there. Singapore as regional HQ for the Far East and the Malaysian site had to tap into that expertise. Materializing this remote knowledge transfer appeared challenging. Americans were confronted with questions that related to their expertise but came from a different operational environment. Simultaneously, people from Far East sites were not completely aware of their knowledge needs, let alone explain them to remote counterparts with a different experience base. Pressure on the remote knowledge transfer process further increased by the fixed deadline. Interwoven with this problem were time zone differences that complicated and delayed exchanges.

People in Singapore and Malaysia developed several strategies to deal with this problem situation. They assessed the criticality of their collaborative dependence, and adapted their contacting modes. The more critical exchange with US colleagues became, the more a shift occurred towards synchronous media, and the more adaptation occurred on both sides. A Singaporean team member explains:

"Sometimes if the problem can be solved in a day it takes 2 days because it's in the middle of the night and when they receive it, it's the next day for them. And then they send a mail back and again it's the next day.

So it is based on the criticality. We used to stay back in the evenings and send a mail and usually they read it in the morning (US time - author). In the morning it is around 8-9 PM or somewhere around that on our time (Singapore - author), and they see it, we receive a reply, send a mail immediately and go. If the issue is not very critical then what I used to do is just send a mail in the evening and then 
next day morning I just come and see." - GP, IT team member Singapore, DiskCo-D-1

In view of the above findings, it appears that time zones constitute a barrier for cross contextual interactions. They exacerbate the effects of distance since people are no longer "a phone call away" (HHT, DiskCo-B-1).

\section{Emerging Patterns of Adaptation}

It appears from the above that the social actors' use of technology mediated the ways in which they communicated their perceptions. The technology made it more difficult for the a social actors to arrive at accommodation of their different perspectives. But the technology also increased the resolve to arrive at a shared understanding. This meant that while language had been used to communicate the different perspectives. It limited the extent to which intersubjectivity could be arrived at. Mechanisms for communication and the exchange of individual perceptions emerged. These mechanisms were anticipation of reciprocal behavior, awareness of each other's activities and environments, collaborative dependence on others' actions and expertise. Together these mechanisms could have brought about shared understanding and enabled adaptation to the globally distributed working environment. In this way intersubjectivity could be created and life worlds maintained. In this process, the participants used timestructuring to remote working and shaped their use of language to include symbols. Figure 1 summarizes this analysis:

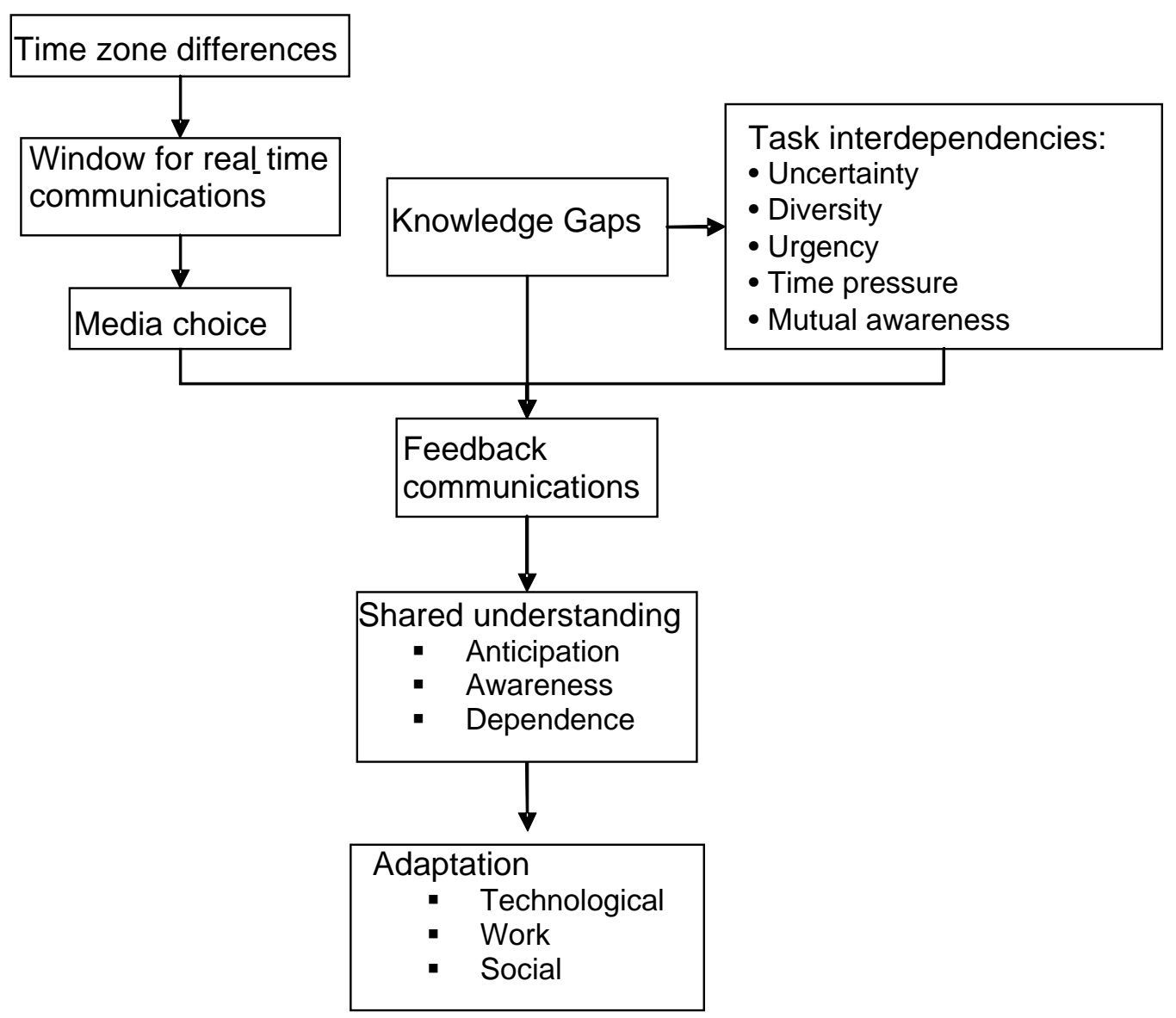

Figure 1 - Forces Leading to Adaptation in Polycontextual Environments 
Adaptation of local time-structuring to remote working conditions for advantageous use of time differences are not always met. Qureshi and Vogel (2001) suggest that three forms of adaptation take place in globally dispersed virtual teams: technological, work and social adaptation. Work adaptation took place in this case as windows for real time exchange became too small for meaningful hand-overs. Common issues demanded elaborate synchronous conversations to resolve different points of view and task unclarity (Abel, 1990). They may surface at times that remote colleagues are not at work, e.g., before or after a window. Or collaborative patterns appear more complicated - e.g., reciprocal, back and forth - than a sequential chain (Van de Ven et al., 1976). Finally, acting in concert like relay racers depends on each participant's understanding and commitment to a common goal - the overarching process. In practice, people may have local priorities or commitments that supersede the interests of remote counterparts. Collective action brought about communications needs and anticipation of reciprocal behavior meant that synchronous contact was embedded in chains of asynchronous exchanges to plan and prepare these. Running the risk of exchange lapses, people adaptively structure their use of media (DeSanctis \& Poole, 1994). As a result interaction processes become more task-oriented and formal. People crafted comprehensive messages that intended to reduce the need for feedback communications.

Technological adaptation took place as the time zones constituted a barrier for cross contextual interactions. The time zones differences exacerbated the effects of distance since people were no longer "a phone call away" (HHT, DiskCo-B-1). Time differences promoted use of asynchronous media like email. These connect people independent of individuals' activity rhythm. At the same time, these media offer limited richness and interactivity (Daft \& Lewin, 1984). They may suffice for minimal exchanges, e.g., between people with extensive shared collaborative experience (Gabarro, 1990). Or in case tasks have been comprehensively structured and documented (Carlson \& Zmud, 1999). However, when people attempted to use email for collaborative tasks, they found themselves caught up in a maelstrom of communication chunks: People spent days bouncing emails back and forth. This delays problem solving, something unacceptable in time-pressed collective tasks.

Social adaptation took place as the social actors studied here developed several strategies for dealing with time differences. (It should be noted that use and relevance thereof depends on task urgency, and how closely activities are intertwined across sites.) A first overall strategy for handling the impacts of time zone differences concerns mutual awareness of each other's activities and environments. People cannot assume their counterpart to be available at any instance. Contacting someone requires one additional step, i.e., considering how late it is elsewhere. This means becoming more time-conscious, both of one's own schedule, and someone else's activity scheme. With time zone differences, people seem to work more deliberately on this mutual orientation by assessing their own activity plan, and communicating frequently with counterparts on this temporal dimension. Connecting across non-overlapping time frames implies loss of things people take for granted. It enhances explicitness within contexts, and increases communications on a polycontextual level such as using symbols to express more complex opinions.

The time zone differences blur boundaries between private and office life. Task pressure and time zone differences increase tensions to get work done despite the complexities associated with distributed collaboration. People adapt working hours and days, and 
sacrifice more of their private time. This sustains connectivity and maintains the pace of inter-site activity flows. Accomplishment of a common task relies on connectivity of activities and expertise. Collaborative dependence on others' actions and expertise range from straightforward exchanges to more challenging interactions. In the latter case, feedback communications are a necessity to bridge diverse life worlds and grasp the uncertainty of a common undertaking (Dougherty, 1992; Thompson, 1967; Watzlawick, Beavin Bavelas, \& Jackson, 1967). In a distributed work environment, time zones modify ways of collaboration that people take for granted in co-located situations. They limit windows for real-time contact and enhance use of asynchronous media, like email.

Similar results have been found in another study. Millar $(1999)^{3}$ conducted interviews in India for a large study on the software industry there. On two occasions, interviewees related to their experiences with time zone differences. Working hours in India hardly overlap with those from customer organizations in the US. This temporal disconnection almost eliminates interactive exchanges that may be demanded for complex problem solving. (Daft \& Lengel, 1986) At the same time, minimal communications in terms of richness and interactivity may suffice since people share collaborative experiences, (Carlson \& Zmud, 1999) or work on a simple task. Under these circumstances, asynchronous communication suffice for relaying work between onshore and offshore. In fact, issues arising later afternoon in the US can be passed on to India and solved overnight without disturbing the customer's work flow.

\section{SUMMARY AND CONCLUSIONS}

This paper has investigated how people work together in a polycontextual work environment in the case of multinational manufacturer's implementation of ERP software in the Far East. The use of phenomenology as a research approach enabled the creation of life worlds through intersubjectivity or the creation of shared understanding to be observed and analyzed. The life of these worlds created through dialogue, images and actions, was reported as quotes derived from interviews with participants intercating in the polycontextual work environments. The data collected from interviews and observations told an interesting story. But this story was disjointed and needed to be pieced together using insights from other similar studies. The data collected from interviews was interpreted through observations and triangulated using results of relevant research conducted in other studies. In this way, this paper has investigated how collective action across multiple time zones can be created through adaptation in polycontextual work environments.

The key challenges facing participants in polycontextual work environments reported in this study are that time zone differences partially disconnect people pursuing a collective endeavor from different sites. Accomplishment of a common task relies on connectivity of activities and expertise. The gaps in knowledge and mutual awareness of those gaps make it very difficult to source expertise and solve problems. In a distributed work environment, time zones modify ways of collaboration that people take for granted in colocated situations. They limit windows for real-time contact and enhance use of asynchronous media, like email. Non-overlapping working hours potentially stretch hours available for a collective endeavor. This demands a sequential process where minimal communications suffice for relaying work at the end of a working day. While there is a

3 Dr. Millar kindly sent us transcripts from her interviews, and granted permission for quotation and analysis. 
sense that the receiving site should be located west from the transmitting so that work follows in a sense the sun so that issues get solved overnight, saving time the next working day. In practice, conditions for advantageous use of time differences are not always met. Windows for real time exchange may be too small for meaningful handovers. Common issues may demand elaborate synchronous conversations to resolve different points of view and task unclarity. They may surface at times that remote colleagues are not at work, e.g., before or after a window. Finally, acting in concert like relay racers depends on each participant's understanding and commitment to a common goal - the overarching process. In practice, people may have local priorities or commitments that supersede the interests of remote counterparts.

The research reported in this paper suggests that these challenges can be overcome through shifts in media choice and crafting comprehensive messages to reduce information dependence. Feedback communications are a necessity to bridge diverse life worlds and grasp the uncertainty of a common undertaking. Shared understanding can be developed through asynchronous documented communication that was structured and formal. The participants can learn to anticipate each others' positions and follow up with conference calls. Participants may develop strategies to adapt to the polycontextual work environment. Such a strategy can be to adapt working hours to create artificial windows that fall outside regular working hours. Adaptation takes place in work, technological and social forms. The analysis in this paper outlines how all three forms of adaptation actually took place in the case of the multinational corporation's implementation of an ERP system in the Far East. Armed with a model of the forces leading to adaptation in polycontextual work environments, future efforts in investigating and implementing distributed collaboration can benefit from the constructs developed in this paper.

Future empirical research is needed to test and further develop the concepts developed in this paper. In particular, research into the implications of time zone differences in the environments of "knowledge intensive" workers is needed. Conceptual work remains to be done using cross-disciplinary research in areas such as organization sciences, sociology, and cognitive theory to ascertain the contours of this intriguing phenomenon. The phenomenological approach of this research has been very relevant to an understanding of adaptation in polycontextual work environments. However, more rigorous research is need to ascertain the extent to which the factors leading to adaptation in polycontextual work environments apply to other more diverse settings.

\section{References}

Abel, M. (1990). Experiences in an Exploratory Distributed Organization. In J. Galegher \& R. E. Kraut \& C. Egido (Eds.), Intellectual Teamwork: Social and Technological Foundations of Cooperative Work. Hillsdale, New Jersey: Lawrence Erlbaum Associates.

Adler, P. S., \& Borys, B. (1996). Two types of bureaucracies: Enabling and coercive. Administrative Science Quarterly, 41, 61-89.

Andres, A. (1992). Mondeo: the Story of the Global Car. Luxembourg: Word Publishing \& Publicity Consultants SA.

Berger, P. and Luckmann, T. (1991) The Social Construction of Reality. Harmondsworth:Penguin Books.

Carlson, J. R., \& Zmud, R. W. (1999). Channel expansion theory and the experiental nature of media richness perceptions. Academy of Management Journal, 42(2), 153-170. 
Carmel, E., \& Zettl-Schaffer, K. (1997). Globally Dispersed Software Development Teams: A Definition and Framework. Paper presented at the International Conference on Management of Technology.

Chiesa, V. (1995). Globalizing R\&D Around Centres of Excellence. Long Range Planning, 28(6), 19-28.

Chikudate, N. (1997) "Exploring the Life-world of Organizations by Linguistic Oriented Phenomenology in Sub-cultural analysis of Organizations: A Comparison between Japanese and US Banks." Management International Review. Vol 37 Issue 2 pp:169-183.

Chwe, M. S.-Y. (2001). Rational Ritual: Culture, Coordination, and Common Knowledge. Princeton, NJ: Princeton University Press.

Cramton, C. D. (2001). The mutual knowledge problem and its consequences for dispersed collaboration. Organization Science, 12(3), 346-371.

Daft, R. L., \& Lengel, R. H. (1986). Organizational information requirements, media richness and structural design. Management Science, 32(5), 554-571.

Daft, R. L., \& Lewin, A. Y. (1984). Information richness: A new approach to managerial behavior and organizational design. In L. L. Cummings \& B. M. Staw (Eds.), Research in Organizational Behavior (pp. 191-233). Homewood, IL: JAI.

DeSanctis, G., \& Poole, M. S. (1994). Capturing the Complexity in Advanced Technology Use: Adaptive Structuration Theory. Organization Science, 5(2), 121147.

Dougherty, D. (1992). Interpretive barriers to successful product innovation in large firms. Organization Science, 3(2), 179-202.

Engeström, Y., Engeström, R., \& Kärkkäinen, M. (1995). Polycontextuality and Boundary Crossing in Expert Cognition: Learning and Problem Solving in Complex Work Activities. Learning and Instruction, 5, 319-336.

Evaristo, R., \& van Fenema, P. C. (1999). A Typology of Project Management: Emergence and Evolution of New Forms. International Journal of Project Management, 17(5), 275-281.

Gabarro, J. J. (1990). The development of working relationships. In J. Galegher \& R. E. Kraut \& C. Egido (Eds.), Intellectual teamwork: Social and technological foundations of cooperative work. Hillsdale, New Jersey: Lawrence Erlbaum Associates.

Grant, R. M. (1996a). Prospering in dynamically-competitive environments: Organizational capability as knowledge integration. Organization Science, 7(4), 375-387.

Grant, R. M. (1996b). Toward a knowledge-based theory of the firm. Strategic Management Journal, 17(Winter), 109-122.

Habermas (1984) The Theory of Communicative Action, Cambridge, UK:Polity Press.

Husserl, E. (1982) Ideas Pertaining to a Pure Phenomenology and a Phenomenological Philosophy, Vol 3. The Hague: Martinus Nijhof.

Knoll, K., \& Jarvenpaa, S. L. (1998). Working Together in Global Virtual Teams. In M. Igbaria \& M. Tan (Eds.), The Virtual Workplace (pp. 2-23). Hershey, USA: IDEA Group.

Krauss, R. M., \& Fussell, S. R. (1990). Mutual knowledge and communicative effectiveness. In J. Galegher \& R. E. Kraut \& C. Egido (Eds.), Intellectual teamwork: Social and technological foundations of cooperative work. Hillsdale, New Jersey: Lawrence Erlbaum Associates.

Kumar, K., \& van Dissel, H., G. (1996). Sustainable Collaboration: Managing Conflict and Co-operation in Inter-Organizational Systems. MIS Quarterly, 20(3). 
Lawrence, P. R., \& Lorsch, J. W. (1967). Organization and environment: Managing differentiation and integration. Boston, MA: Harvard University Press.

Lee, A. S. (1991). Integrating Positivist and Interpretive Approaches to Organizational Research. Organization Science, 2(4), 342-365.

Malone, T. W., Crowston, K., Lee, J., \& Pentland, B. (1999). Tools for Inventing Organizations: Towards a Handbook of Organizational Processes. Management Science, 45(11), 65-78.

Markus, M. L., Tanis, C., \& van Fenema, P. C. (2000). Multisite ERP Implementations. Communications of the ACM, 43(4).

Meadows, C. J. (1996a). Globalizing Software Development. Journal of Global Information Management, 4(1), 5-14.

Meadows, C. J. (1996b). Globework: Creating Technology with International Teams (thesis)., Harvard University, Boston.

Merleau-Ponty, M. (1962) Phenomenology of Perception. London:Routledge.

Millar, J. (1999). International Software Trade: Capability Building Through Client Relationships. A submission to: The Information Society.

Ouchi, W. G. (1977). The Relationship between Organizational Structure and Organizational Control. Administrative Science Quarterly, 22(March), 95-113.

Quain, J. R. (1997). Work Together, Apart! Fast Company(October).

Qureshi, S and Zigurs, I. (2001) "Paradoxes and Prerogatives in Global Virtual Collaboration" Communications of the ACM special section on Global Applications of Groupware. 44(12). December.

Qureshi, S. and D. Vogel. (2001) "Organizational Adaptiveness in Virtual Teams". Group Decision and Negotiation. 10(1) pp 27-46.

Schutz, A. (1967) The Phenomenology of the Social World. Evanston, IL: Northwestern University Press.

Searle, J.R. (1995) The construction of Social Reality, New York: Free Press 1995.

Soh, C., Kien, S. S., \& Tay-Yap, J. (2000). Cultural Fits and Misfits: Is ERP a Universal Solution? Communications of the ACM, 43(4), 47-51.

Thompson, J. D. (1967). Organizations in action.: McGraw-Hill.

Van de Ven, A. H., Delbecq, A. L., \& Koenig Jr, R. (1976). Determinants of Coordination Modes Within Organizations. American Sociological Review, 41(April), 322-338.

von Hippel, E. (1994). "Sticky information" and the locus of problem solving: Implications for innovation. Management Science, 40(4), 429-439.

Watzlawick, P., Beavin Bavelas, J., \& Jackson, D. D. (1967). Pragmatics of human communication: A study of interactional patterns, pathologies, and paradoxes. New York: W.W. Norton.

Weick, K. E. (1993). The collapse of sensemaking in organizations: The Mann Gulch disaster. Administrative Science Quarterly, 38, 628-652.

Weick, K. E., \& Roberts, K. (1993). Collective mind in organizations: Heedful interelating on flight decks. Administrative Science Quarterly, 38, 357-381.

Weick, K. E. (2001) Making Sense of the Organization. Oxford: Blackwell.

Williamson, O. E. (1985). The Economic Institutions of Capitalism: Firms, Markets, Relational Contracting. New York: Free Press.

Williamson, O. E. (1991). Comparative economic organization: The analysis of discrete structural alternatives. Administrative Science Quarterly, 36, 269-296. 


\section{Publications in the Report Series Research* in Management}

\section{ERIM Research Program: "Business Processes, Logistics and Information Systems"}

\section{4}

Smart Pricing: Linking Pricing Decisions with Operational Insights

Moritz Fleischmann, Joseph M. Hall and David F. Pyke

ERS-2004-001-LIS

http://hdl.handle.net/1765/1114

Mobile operators as banks or vice-versa? and: the challenges of Mobile channels for banks

L-F Pau

ERS-2004-015-LIS

http://hdl.handle.net/1765/1163

Simulation-based solution of stochastic mathematical programs with complementarity constraints: Sample-path analysis S. Ilker Birbil, Gül Gürkan and Ovidiu Listeş ERS-2004-016-LIS

http://hdl.handle.net/1765/1164

Combining economic and social goals in the design of production systems by using ergonomics standards Jan Dul, Henk de Vries, Sandra Verschoof, Wietske Eveleens and Albert Feilzer

ERS-2004-020-LIS

http://hdl.handle.net/1765/1200

Factory Gate Pricing: An Analysis of the Dutch Retail Distribution

H.M. le Blanc, F. Cruijssen, H.A. Fleuren, M.B.M. de Koster

ERS-2004-023-LIS

http://hdl.handle.net/1765/1443

A Review Of Design And Control Of Automated Guided Vehicle Systems

Tuan Le-Anh and M.B.M. De Koster

ERS-2004-030-LIS

http://hdl.handle.net/1765/1323

Online Dispatching Rules For Vehicle-Based Internal Transport Systems

Tuan Le-Anh and M.B.M. De Koster

ERS-2004-031-LIS

http://hdl.handle.net/1765/1324

Generalized Fractional Programming With User Interaction

S.I. Birbil, J.B.G. Frenk and S. Zhang

ERS-2004-033-LIS

http://hdl.handle.net/1765/1325

\footnotetext{
* A complete overview of the ERIM Report Series Research in Management: https://ep.eur.nl/handle/1765/1

ERIM Research Programs:

LIS Business Processes, Logistics and Information Systems

ORG Organizing for Performance

MKT Marketing

F\&A Finance and Accounting

STR Strategy and Entrepreneurship
} 
Learning Opportunities And Learning Behaviours Of Small Business Starters: Relations With Goal

Achievement, Skill Development, And Satisfaction

Marco van Gelderen, Lidewey van der Sluis \& Paul Jansen

ERS-2004-037-ORG

http://hdl.handle.net/1765/1429

Meta-heuristics for dynamic lot sizing: A review and comparison of solution approaches

Raf Jans and Zeger Degraeve

ERS-2004-042-LIS

http://hdl.handle.net/1765/1336

\author{
A Multi-Item Inventory Model With Joint Setup And Concave Production Costs \\ Z.P. Bayındır, S.I. Birbil and J.B.G. Frenk \\ ERS-2004-044-LIS \\ http://hdl.handle.net/1765/1535 \\ The Level Set Method Of Joó And Its Use In Minimax Theory \\ J.B.G. Frenk and G. Kassay \\ ERS-2004-045-LIS \\ http://hdl.handle.net/1765/1537 \\ Reinventing Crew Scheduling At Netherlands Railways \\ Erwin Abbink, Matteo Fischetti, Leo Kroon, Gerrit Timmer And Michiel Vromans \\ ERS-2004-046-LIS \\ http://hdl.handle.net/1765/1427
}

Intense Collaboration In Globally Distributed Teams: Evolving Patterns Of Dependencies And Coordination

Kuldeep Kumar, Paul C. van Fenema and Mary Ann Von Glinow

ERS-2004-052-LIS

http://hdl.handle.net/1765/1446

The Value Of Information In Reverse Logistics

Michael E. Ketzenberg, Erwin van der Laan and Ruud H. Teunter

ERS-2004-053-LIS

http://hdl.handle.net/1765/1447

Cargo Revenue Management: Bid-Prices For A 0-1 Multi Knapsack Problem

Kevin Pak and Rommert Dekker

ERS-2004-055-LIS

http://hdl.handle.net/1765/1449

Real-Time Scheduling Approaches For Vehicle-Based Internal Transport Systems

Tuan Le-Anh and M.B.M. De Koster

ERS-2004-056-LIS

http://hdl.handle.net/1765/1452

Individual Telecommunications Tariffs in Chinese Communities: History as a Mirror of the Future, and

Relevance for Mobile Service Development in China

H.Chen; L-F Pau

ERS-2004-057-LIS

http://hdl.handle.net/1765/1582

Activating Knowledge Through Electronic Collaboration: Vanquishing The Knowledge Paradox

S. Qureshi and P. Keen

ERS-2004-058-LIS

http://hdl.handle.net/1765/1473 
A Grounded Theory Analysis Of E-Collaboration Effects For Distributed Project Management

S. Qureshi, M. Liu and D. Vogel

ERS-2004-059-LIS

http://hdl.handle.net/1765/1448

Collaborative Infrastructures For Mobilizing Intellectual Resources: Assessing Intellectual Bandwidth In A

Knowledge Intensive Organization

R. Verhoef and S. Qureshi

ERS-2004-060-LIS

http://hdl.handle.net/1765/1474

A Phenomenological Exploration Of Adaptation In A Polycontextual Work Environment

P.C. van Fenema and S. Qureshi

ERS-2004-061-LIS

Satisfaction Attainment Theory As A Model For Value Creation

R.O. Briggs, S. Qureshi and B. Reining

ERS-2004-062-LIS

http://hdl.handle.net/1765/1450

Diagnosis In The Olap Context

Emiel Caron, Hennie Daniels

ERS-2004-063-LIS

http://hdl.handle.net/1765/1492

A Deterministic Inventory/Production Model With General Inventory Cost Rate Function And Concave Production Costs Z.P. Bayındır, S.I. Birbil and J.B.G. Frenk

ERS-2004-064-LIS

http://hdl.handle.net/1765/1536

On And Off The Beaten Path: How Individuals Broker Knowledge Through Formal And Informal Networks

Rick Aalbers, Wilfred Dolfsma \& Otto Koppius

ERS-2004-066-LIS/ORG

http://hdl.handle.net/1765/1549

Fractional Programming

J.B.G. Frenk And S. Schaible

ERS-2004-074-LIS

http://hdl.handle.net/1765/1610

Introduction To Convex And Quasiconvex Analysis

J.B.G. Frenk and G. Kassay

ERS-2004-075-LIS

http://hdl.handle.net/1765/1611 